DOI: 10.1590/1980-549720200011.supl.1

ORIGINAL ARTICLE / ARTIGO ORIGINAL

Helmet use and injury severity among crashed motorcyclists in Brazilian state capitals: an analysis of the violence an accidents survey 2017

\title{
Uso de capacete e gravidade de lesões em motociclistas vitimas de acidentes de trânsito nas capitais brasileiras: uma análise do Viva Inquérito 2017
}

\author{
Rayone Moreira Costa Veloso Souto' (D), Rafael Bello Corassa' (iD, Cheila Marina de Lima' (iD, \\ Deborah Carvalho Malta" (D)
}

ABSTRACT: Objective: To analyze the effect of helmet use on injury severity among motorcyclists and passengers involved in traffic accidents. Methods: Cross-sectional study of traffic accidents involving motorcyclists attended at the emergency healthcare units participating in the Violence and Accidents Survey Conducted in Sentinel Emergency Departments (Viva Survey) 2017. Results: There was a predominance of individuals aged 18 to 29 years old (46.6\%), black (75.2\%), with high school education (50.6\%). Alcohol use was observed in $14.1 \%$ of cases. Helmet use was associated with a $76 \%$ reduction in the occurrence of head trauma and a $28 \%$ reduction in the referral, hospitalization or death. Conclusion: Young, male, black individuals and those with low education were the most frequent victims of accidents. Helmet use was protective for severe injuries.

Keywords: External causes. Traffic accidents. Health surveys. Ambulatory care. Patient acuity. Motorcycles.

'Department of Health Analysis and Surveillance of Noncommunicable Disease, Secretariat of Health Surveillance, Ministry of Health - Brasília (DF), Brazil.

"Universidade Federal de Minas Gerais - Belo Horizonte (MG), Brazil.

Corresponding author: Rayone Moreira Costa Veloso Souto. Ministério da Saúde. SRTVN 701, Via W5 Norte, Ed. P0700, $6^{\circ}$ andar. CEP: 70723-040, Brasilia, DF, Brasil. E-mail: rayone.costa@saude.gov.br

Conflict of interests: nothing to declare - Financial support: none. 
RESUMO: Objetivo: Analisar o efeito do uso de capacete na gravidade de lesões em condutores e passageiros de motocicletas envolvidos em acidentes de trânsito. Métodos: Estudo de corte seccional sobre vítimas de acidentes de transporte terrestre envolvendo motociclistas, atendidos nos serviços de urgência e emergência e participantes do Inquérito de Vigilância de Violências e Acidentes (Viva Inquérito) 2017. Resultados: Verificou-se predomínio de indivíduos na faixa de 18 a 29 anos (46,6\%), negros (75,2\%) e com ensino médio (50,6\%). Em 14,1\% dos acidentes houve relato de uso de álcool. O uso do capacete reduziu em $76 \%$ a ocorrência de trauma cranioencefálico e em $28 \%$ a ocorrência de encaminhamento para outro hospital, internação ou óbito. Conclusão: Motociclistas jovens, negros, de baixa escolaridade e do sexo masculino apresentaram-se mais vulneráveis aos acidentes. O uso do capacete mostrou-se protetor para lesões graves.

Palavras-chave: Causas externas. Acidentes de trânsito. Inquéritos epidemiológicos. Assistência ambulatorial. Gravidade do paciente. Motocicletas.

\section{INTRODUCTION}

Trauma caused by traffic accidents result in important social, economic, environmental and health impacts, in addition to overloading health services ${ }^{1}$. In 2013 , deaths and injuries from this cause were responsible for an overall cost of $3 \%$ of the global gross domestic product (GDP), and in low- and middle-income countries, this cost reached $5 \%$ of the GDP ${ }^{2}$.

In Brazil, traffic accidents are the second leading cause of death among all external causes of mortality, with a higher occurrence in the population aged 15 to 39 years old. The main fatal victims are motorcyclists, who represent about one third of deaths from traffic accidents ${ }^{1}$. From 2004 to 2013, there was an increasing trend in mortality in this group, with an increment in the average annual rate of $7.98 \%(95 \% \text { CI } 5.71-10.29)^{3}$. Between 2010 and 2017 , there was a reduction in the number of deaths in all groups of victims of traffic accidents, with the exception of motorcyclists, mainly in the North and Northeast regions ${ }^{4}$.

The causality of accidents among motorcyclists involves multiple factors, such as vulnerability due to the type of vehicle, vertiginous increase in the fleet, lack of road and vehicle safety, risky behaviors ${ }^{2,5}$, in addition to the increasing use of this vehicle as a work tool, without proper approaches to ensure work safety ${ }^{6}$. One of the preventable factors that contribute to the increase in the severity of injuries in motorcyclists refers to the lack of use of protective equipment. Cranioencephalic injuries, for example, are directly related to not wearing a helmet ${ }^{1}$.

Knowing the factors that influence the use of protective equipment as well as the effectiveness of these devices for preventing serious injuries and deaths is fundamental to plan and improve public policies and guide law enforcement actions and educational campaigns. Thus, this study aims to describe the characteristics of traffic accidents among motorcyclists and to analyze the factors associated with helmet use, as well as the effect of this use on injury severity. 


\section{METHODS}

Cross-sectional study on motorcyclists victims of traffic accidents admitted to emergency departments that participated in the Violence and Accident Survey (Inquérito de Vigilância de Violências e Acidentes - Viva Survey) 2017. Data were collected during 30 consecutive days, between September and December 2017, in services enabled for emergency care within the scope of the Unified Health System (Sistema Único de Saúde - SUS) of 23 Brazilian state capitals and the Federal District.

The sample calculation considered the number of admissions by external causes in each emergency unit in September 2016. A minimum sample of two thousand visits was calculated, considering a variation coefficient $<30.0 \%$, standard error $<3$ and design effect $($ deff $)=2$. A probabilistic one-stage clustered sampling approach was used to select 12-hour day and night shifts stratified by the type of healthcare unit (emergency care unit, hospital, and specialized health service). The number of shifts in each service was calculated by dividing the minimum sample size by the average number of admissions by external causes in the same unit in previous editions of Viva Survey.

Data were collected using a standardized form applied by trained interviewers. All admissions from external causes in the selected shifts were deemed eligible, except for individuals who sought care for the same occurrence more than once, such as situations of medical returns and/or complications of assistance.

Motorcyclists were defined as anyone who travels by motorcycle or in a sidecar or trailer attached to this type of vehicle, including drivers and passengers. The analysis was restricted to motorcyclists admitted to public emergency care services due to traffic accidents. The variables analyzed were gender (male; female), age group ( 0 to $9 ; 10$ to $17 ; 18$ to 29; 30 years old or older), self-declared race / color (white; black [black and brown]; yellow / indigenous), education (up to elementary school; high school; higher education), type of victim (driver; passenger), nature of the injury (without physical injury; contusion, sprain/ dislocation; cut/laceration; traumatic brain injury (TBI); others), affected body part (head/ neck/spine; trunk/upper limbs; lower limbs; multiple organs), helmet use (yes; no), alcohol consumption (yes; no), work-related event (yes; no), and evolution (discharge/ evasion; referral/hospitalization/death).

Descriptive analyses of the sample characteristics regarding traffic accidents involving motorcyclists were carried out according to sociodemographic characteristics by driver and non-driver. The frequencies of helmet use were described and the associations between helmet use and the severity of injuries among motorcyclists were analyzed. The occurrence of TBI and case progression to referral to another hospital, hospitalization or death were considered proxies for injury severity. All analyses were stratified according to the type of victim (drivers and passengers), after which an aggregated analysis of drivers and passengers was carried out.

Bivariate associations were analyzed using the $\chi^{2}$ test, with second-order Rao-Scott correction for complex samples. Prevalence ratios and their confidence intervals were calculated 
using Poisson regression with robust variance. Multivariate analyses of the associations between the use of helmets and the occurrence of TBI and the case progression were also carried out in order to obtain the prevalence ratios adjusted for other variables that could contribute to the severity of the injury. The selection of adjustment variables was performed with the aid of a directed acyclic diagram (DAG). Age of the victim and use of alcohol by the driver were retained as adjustment variables in the model. Since only the use of alcohol by the driver was relevant for adjustment, and considering that there is no information about the driver whenever the admitted person was a passenger, this variable was included only in the analysis of injured drivers.

The analyses were performed using the survey module of Stata, version 14, considering the complex sampling strategy. All analyses were performed considering a significance level of $5 \%$.

The Viva Survey Project was approved by the National Commission for Ethics in Research (Conep) of the Ministry of Health, under Opinion No. 2.234.509, 8/23/2017 — Certificate of Presentation for Ethical Appreciation (CAAE): 67709417.0.0000.0008. Data collection was carried out after the verbal agreement of the victims, or their guardians or caregivers when they were under 18 or unconscious.

\section{RESULTS}

Traffic accidents accounted for 11,802 emergency admissions, of which 7,813 (62.6\%) were accidents involving motorcyclists. Ten cases were excluded from the analysis because the victims were not classified as drivers or passengers of the vehicle.

Injured motorcycle occupants were mainly aged 18 to 29 years old (46.6\%), black $(75.2 \%)$, and with high school education (50.9\%). Alcohol use in the six hours prior to the occurrence was reported by $14.1 \%$ of injured motorcyclists and approximately onethird of the accidents were related to work. Comparing injured passengers and drivers, there was a predominance of men among drivers (86.6\%) and women among passengers (64.5\%) (Table 1).

The most frequent injuries were bruises, sprains/dislocations (33.4\%), and cuts/ lacerations (29.2\%). TBI was observed in $2.9 \%$ of the sample. The lower limbs were the most affected parts of the body (42.2\%), followed by upper limbs/trunk $(29.9 \%)$ and multiple organs (16.0\%). Head/neck/spine injuries were affected in $12.0 \%$ of cases (Table 2).

The mean prevalence of helmet use among admitted injured motorcycle occupants was $81.8 \%$ (95\%CI 79.8 - 83.6), ranging from 97.6\% (95\%CI 95.8 - 98.6) in Cuiabá (MS) to 53.8\% (95\%CI 45.4-62.0) in Belém (PA) (Figure 1).

There were lower proportions of helmet use among young people, under 18 years of age, blacks (PR $=0.93 ; 95 \% \mathrm{CI} 0.90-0.96)$ and who used alcohol $(\mathrm{PR}=0.74 ; 95 \% \mathrm{CI} 0.70-$ 0.79 ), and higher proportions of equipment use among individuals with higher education, 
involved in work-related accidents $(\mathrm{PR}=1.20 ; 95 \% \mathrm{CI} 1.15-1.25)$ and among drivers $(\mathrm{PR}=1.11 ; 95 \% \mathrm{CI} 1.07-1.15)$ compared to passengers (Table 3$)$.

Helmet use was associated with a $76 \%$ reduction $(\mathrm{PR}=0.24 ; 95 \% \mathrm{CI} 0.18-0.32)$ in the occurrence of traumatic brain injury and a $28 \%$ reduction $(\mathrm{PR}=0.72 ; 95 \% \mathrm{CI} 0.62$ 0.83 ) in referrals to other services, hospitalizations or deaths, compared to discharge/ evasion (Table 4).

\section{DISCUSSION}

The results of this study pointed out the vulnerability of motorcyclists to accidents and the importance of wearing a helmet in reducing the severity of injuries. Despite the

Table 1. Emergency care for accidents involving motorcyclists, according to the victim's characteristics, alcohol use and relationship with work, by type of victim. Selected services in

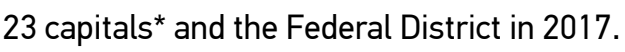

\begin{tabular}{|c|c|c|c|c|c|c|c|}
\hline \multirow{2}{*}{\multicolumn{2}{|c|}{ Characteristics }} & \multicolumn{2}{|c|}{$\begin{array}{l}\text { Passenger } \\
(n=1,380)\end{array}$} & \multicolumn{2}{|c|}{$\begin{array}{c}\text { Driver } \\
(n=6,423)\end{array}$} & \multicolumn{2}{|c|}{$\begin{array}{c}\text { Passenger and } \\
\text { Driver } \\
(\mathrm{n}=7,803)\end{array}$} \\
\hline & & $\mathrm{n}$ & $\%^{* *}$ & $\mathrm{n}$ & $\%^{* *}$ & $\mathrm{n}$ & $\% * *$ \\
\hline \multirow[b]{2}{*}{ Gender*** } & Female & 905 & 64.5 & 1,011 & 13.4 & 1,916 & 22,8 \\
\hline & Male & 475 & 35.5 & 5,412 & 86.6 & 5,887 & 77,2 \\
\hline \multirow{4}{*}{ Age range $\mathrm{e}^{\star * *}$} & 0 to 9 years & 78 & 4.4 & 11 & 0.1 & 89 & 0.9 \\
\hline & 10 to 17 years & 219 & 15.3 & 256 & 4.2 & 475 & 6.2 \\
\hline & 18 to 29 years & 565 & 42.5 & 3,070 & 47.5 & 3,635 & 46.6 \\
\hline & 30 years+ & 517 & 37.9 & 3,080 & 48.3 & 3,597 & 46.3 \\
\hline \multirow{3}{*}{ Race/Color } & White/Caucasian & 275 & 22.3 & 1,318 & 22.5 & 1,593 & 22.5 \\
\hline & Black & 1,033 & 74.8 & 4,798 & 75.3 & 5,831 & 75.2 \\
\hline & Yellow/Indigenous & 36 & 2.8 & 153 & 2.3 & 189 & 2.4 \\
\hline \multirow{3}{*}{ Education $^{* \star *}$} & Up to elementar school & 571 & 43.1 & 2,268 & 36.6 & 2,839 & 37.9 \\
\hline & High school & 586 & 46.8 & 3,158 & 51.8 & 3,744 & 50.9 \\
\hline & Higher education & 133 & 10.2 & 708 & 11.5 & 841 & 11.3 \\
\hline \multicolumn{2}{|c|}{ Work-related event ${ }^{* * *}$} & 265 & 22.0 & 2,109 & 37.7 & 2,374 & 34.8 \\
\hline \multicolumn{2}{|c|}{ Suspected use of alcohol } & 159 & 13.3 & 898 & 14.2 & 1,057 & 14.1 \\
\hline
\end{tabular}

*Macapá, Florianópolis and Porto Alegre were not included in the research; ${ }^{* *}$ weighted percentage; ${ }^{* * *} \mathrm{p}<0.05$. 
relevance of these findings, it is important to note that this study used data on care provided only by intentionally selected public emergency care services that were considered to be local references for treatment of external causes, which limits the possibility of generalization results.

The study showed that young people, aged 18 to 29 years old, black, and male were the main victims of traffic accidents involving motorcycles admitted to the selected emergency care units. More than a third of the events were work-related, and $15 \%$ of the injured persons were under the influence of alcohol. The lower limbs were the most frequently affected parts of the body, and TBI was observed in $2.9 \%$ of the sample. More educated individuals and motorcyclists who used the vehicle for work reasons were more likely to be wearing a helmet. Individuals who wore the helmet at the time of the accident had a $76 \%$ reduction in the occurrence of traumatic brain injury and about $30 \%$ reduction in referrals to other services, hospitalizations or deaths.

Table 2. Emergency care for accidents involving motorcyclists, according to the characteristics of the

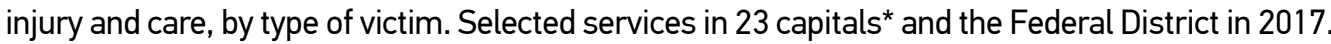

\begin{tabular}{|c|c|c|c|c|c|c|}
\hline \multirow[t]{2}{*}{ Characteristics } & \multicolumn{2}{|c|}{$\begin{array}{l}\text { Passenger } \\
(\mathrm{n}=1,380)\end{array}$} & \multicolumn{2}{|c|}{$\begin{array}{c}\text { Driver } \\
(n=6,423)\end{array}$} & \multicolumn{2}{|c|}{$\begin{array}{c}\text { Passenger and } \\
\text { Driver } \\
(n=7,803)\end{array}$} \\
\hline & $\mathrm{n}$ & $\%^{* *}$ & $\mathrm{n}$ & $\%$ ** & $\mathrm{n}$ & $\%$ ** \\
\hline \multicolumn{7}{|l|}{ Nature of the injury ${ }^{* \star \star *}$} \\
\hline No physical injury & 55 & 3.2 & 138 & 2.1 & 193 & 2.3 \\
\hline Contusion, sprain/dislocation & 719 & 36.0 & 1,700 & 32.8 & 2,419 & 33.4 \\
\hline Cut/laceration & 560 & 29.7 & 1,825 & 29.1 & 2,385 & 29.2 \\
\hline Head trauma & 27 & 2.5 & 164 & 3.0 & 191 & 2.9 \\
\hline Others ${ }^{* * *}$ & 535 & 28.5 & 2,002 & 33 & 2,537 & 32.1 \\
\hline \multicolumn{7}{|l|}{ Affected part of the body ${ }^{\star \star \star *}$} \\
\hline Head/Neck/Spine & 206 & 11.9 & 673 & 12.0 & 879 & 12.0 \\
\hline Trunk/Upper limbs & 487 & 24.2 & 1,804 & 31.1 & 2,291 & 29.9 \\
\hline Lower limbs & 852 & 46.2 & 2,273 & 41.3 & 3,125 & 42.2 \\
\hline Multiple organs & 291 & 17.6 & 945 & 15.7 & 1,236 & 16.0 \\
\hline \multicolumn{7}{|l|}{ Evolution } \\
\hline Discharge/Evasion & 1,381 & 76.0 & 4,027 & 72.6 & 5,408 & 73.2 \\
\hline Referral/Hospitalization/Death & 456 & 24.0 & 1,636 & 27.4 & 2,092 & 26.8 \\
\hline
\end{tabular}

*Macapá, Florianópolis and Porto Alegre were not included in the research; **weighted percentage; ***includes fractures, amputations, dentl trauma, polytrauma and other types of injury; ${ }^{* * *} p<0.05$. 
Traffic accidents involving motorcycles result in high mortality rates in Brazil, as pointed out by several studies ${ }^{7-11}$, with an increasing trend from 2000 to $2015^{7}$. This epidemic of deaths results from multiple factors, such as the rapid growth of the motorcycle fleet in the country, the precarious road infrastructure, the sharing of roads, in addition to behavioral issues such as excessive speed, alcohol use and not wearing a helmet $^{16-18}$. It is noteworthy that the growth of the motorcycle fleet, in the last decades, concentrated mainly in the North, Northeast and Midwest regions and in small municipalities. This was due to the replacement of non-motorized means of transportation, such as bicycles and animals, by motorcycles ${ }^{2,7}$, due to its low maintenance costs ${ }^{12}$, improved traffic fluidity, lack of quality in public transports ${ }^{13,14}$ and tax incentives for buying this type of vehicle $\mathrm{e}^{7,15}$.

The high number of work-related motorcycle accidents requires further studies on work relationships and strategies related to work safety ${ }^{1}$. Contributing factors to these accidents are the demands and pressure from employers and customers for fast services, excessive working hours, precarious working relationships, in addition to inadequate road infrastructure $^{6,17-20}$. Data from the National Health Survey (Pesquisa Nacional de Saúde - PNS), a survey of national representativeness of the domiciled population, carried out in 2013, showed that $30 \%$ of work accidents, about 1.9 million accidents, occurred while commuting to the work place ${ }^{21}$.

The association of alcohol use and driving was observed in about $15 \%$ of the events. Driving under the influence of alcohol has been considered one of the main risk factors for the occurrence of traffic accidents as it affects the driver's reflexes and increases risky choices,

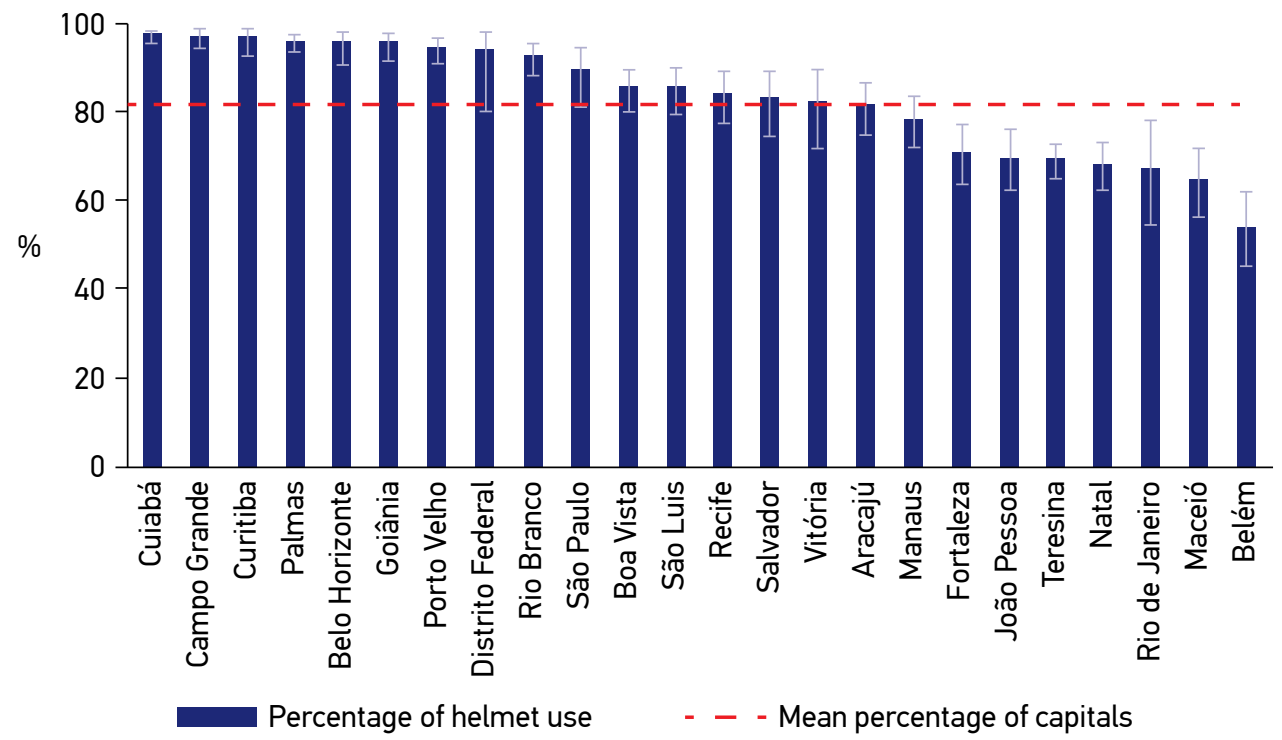

*Macapá, Florianópolis, and Porto Alegre were not included in the research.

Figure 1. Frequency of helmet use in the total of drivers and passengers attended by motorcycle

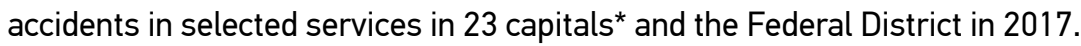


such as transgression of traffic legislation ${ }^{21,22}$. According to results of the Surveillance System for Risk and Protective Factors for Chronic Diseases by Telephone Survey (Vigilância de Fatores de Risco e Proteção para Doenças Crônicas por Inquérito Telefônico - Vigitel), a telephone survey representative of the population with landline telephony in Brazilian capitals, conducted in 2018, the frequency of adults who reported driving motor vehicles after drinking alcoholic beverages was $11.4 \%$ for the group of Brazilian capitals, varying from $5.7 \%$ in Recife to $24.1 \%$ in Teresina ${ }^{23}$. In 2013, data from the PNS 2013 also showed that between 30 and $39 \%$ of people over 18 years of age who drink and drive cars or motorcycles drove under the effect of alcohol ${ }^{24}$, with a two-times-greater chance of a traffic accident among those who drive after drinking alcohol ${ }^{25}$. In addition, drivers who suffered an accident after using alcohol were mostly young men ${ }^{25}$.

The characteristics of the injuries, with a high number of cuts, lacerations and TBI associated with the high percentage of hospitalization, referral to another hospital and death,

Table 3. Emergency care for accidents involving motorcyclists, according to sociodemographic characteristics of drivers, wearing a helmet. Selected services in 23 capitals* $^{*}$ and the Federal District in 2017.

\begin{tabular}{|c|c|c|c|c|c|}
\hline \multicolumn{2}{|c|}{ Characteristics } & $\%^{* *}$ & $p$ & PR & $95 \% \mathrm{Cl}$ \\
\hline \multirow{2}{*}{ Gender } & Female & 78.9 & 0.162 & & \\
\hline & Male & 80.8 & & & \\
\hline \multirow{4}{*}{ Age range } & 0 to 9 years & 51.5 & $<0.001$ & 0.63 & $0.50-0.79$ \\
\hline & 10 to 17 years & 57.4 & & 0.70 & $0.63-0.78$ \\
\hline & 18 to 29 years & 81.7 & & Ref. & \\
\hline & 30 years+ & 82.6 & & 1.01 & $0.98-1.04$ \\
\hline \multirow{3}{*}{ Race/Color } & White/Caucasian & 84.9 & $<0.001$ & Ref. & \\
\hline & Black & 78.8 & & 0.93 & $0.90-0.96$ \\
\hline & Yellow/Indigenous & 86.0 & & 1.01 & $0.95-1.08$ \\
\hline \multirow{3}{*}{ Education } & Up to elementar school & 73.3 & $<0.001$ & Ref. & \\
\hline & High school & 83.6 & & 1.14 & $1.10-1.18$ \\
\hline & Higher education & 91.4 & & 1.25 & $1.19-1.30$ \\
\hline \multirow{2}{*}{ Occupant } & Passenger & 73.8 & $<0.001$ & Ref. & \\
\hline & Driver & 81.8 & & 1.11 & $1.07-1.15$ \\
\hline \multicolumn{2}{|c|}{ Work-related event } & 9.4 & $<0.001$ & 1.20 & $1.15-1.25$ \\
\hline \multicolumn{2}{|c|}{ Suspected use of alcohol } & 62.6 & $<0.001$ & 0.74 & $0.70-0.79$ \\
\hline
\end{tabular}


reveal the magnitude and severity of injuries in motorcyclists. In addition, it is emphasized that TBI is directly related to not wearing a helmet ${ }^{1}$.

Motorcycles are considered to be one of the most dangerous forms of motorized transport due to the small size of the vehicle and the absence of the structure and protective devices that are present in cars, resulting in greater exposure of the occupants to the impact and greater vulnerability to multiple and more severe trauma ${ }^{26,27}$. This vulnerability is even greater when there is a division of road space with larger vehicles ${ }^{16}$, resulting in a 30 times greater risk of death, when compared to the risk that occupants of other types of motorized vehicles are exposed ${ }^{28,29}$. Thus, motorcyclists suffer disproportionately higher risks and more severe injuries from traffic accidents.

The current study showed that an important proportion of the victims did not wear a helmet, despite their mandatory status in the country ${ }^{30-32}$. Enacting and enforcing laws to address risk factors is an effective measure to reduce deaths and injuries from traffic accidents $^{33}$, with a major impact on the severity of these accidents ${ }^{34}$. This study reinforces the importance of the helmet as a safety device to prevent serious injuries. These findings are in accordance with evidence from the World Health Organization, which points to the

Table 4. Emergency care for accidents involving motorcyclists, according to type of injury, evolution, and type of victim. Selected services in 23 capitals* and the Federal District in 2017.

\begin{tabular}{|c|c|c|c|c|c|c|}
\hline \multicolumn{3}{|l|}{ 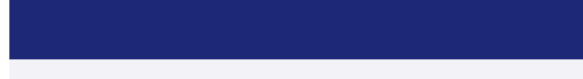 } & Gross PR & $95 \% \mathrm{Cl}$ & Adjusted PR & $95 \% \mathrm{Cl}$ \\
\hline \multicolumn{7}{|l|}{ Head trauma } \\
\hline \multirow{2}{*}{$\begin{array}{l}\text { Driver and } \\
\text { Passenger }^{* *}\end{array}$} & Without helmet & 8.13 & Ref. & & Ref. & \\
\hline & With helmet & 1.82 & 0.24 & $0.18-0.32$ & 0.24 & $0.18-0.32$ \\
\hline \multirow{2}{*}{ Driver ${ }^{* * *}$} & Without helmet & 8.13 & Ref. & & Ref. & \\
\hline & With helmet & 1.82 & 0.22 & $0.16-0.31$ & 0.25 & $0.17-0.36$ \\
\hline \multirow{2}{*}{ Passenger ${ }^{* *}$} & Without helmet & 5.4 & Ref. & & Ref. & \\
\hline & With helmet & 1.7 & 0.31 & $0.17-0.58$ & 0.33 & $0.17-0.62$ \\
\hline \multicolumn{7}{|c|}{ Referral to other hospitals/Hospitalization/Death } \\
\hline \multirow{2}{*}{$\begin{array}{l}\text { Driver and } \\
\text { Passenger }\end{array}$} & Without helmet & 22.69 & Ref. & & Ref. & \\
\hline & With helmet & 16.37 & 0.72 & $0.62-0.84$ & 0.72 & $0.62-0.83$ \\
\hline \multirow{2}{*}{ Driver ${ }^{* \star *}$} & Without helmet & 23.83 & Ref. & & Ref. & \\
\hline & With helmet & 16.97 & 0.71 & $0.61-0.84$ & 0.80 & $0.66-0.97$ \\
\hline \multirow{2}{*}{ Passenger** } & Without helmet & 19.19 & Ref. & & Ref. & \\
\hline & With helmet & 13.36 & 0.7 & $0.5-0.97$ & 0.71 & $0.52-0.98$ \\
\hline
\end{tabular}

*Except Macapá, Florianópolis, and Porto Alegre; **weighted percentage; ***analyses adjusted by age and driver alcohol use; PR: prevalence ration; $95 \% \mathrm{Cl}$ : 95\% confidence interval; Ref.: reference. 
protective effect of helmet use, with a $70 \%$ reduction in the chances of TBI and up to a $40 \%$ reduction in the chances of death ${ }^{17}$.

The study also revealed that young, black, low-educated, and male motorcyclists are more vulnerable to motorcycle accidents. The use of the helmet is shown to be protective against serious injuries, showing the importance of intensifying educational and law-enforcement measures ${ }^{1}$ focused on motorcyclists and aiming the use of the helmet, considering its effectiveness in preventing severe injuries.

In Brazil, among the strategies to face the problem, the Life in Traffic Program (Programa Vida no Trânsito - PVT) stands out as the main national response to the challenges of the United Nations' global target for road safety and the Sustainable Development Goals (SDG). The PVT is a management and governance strategy focused on integrated actions, guided by local evidence and integrated data analysis, carried out through intersectoral plans, aiming to reduce morbidity and mortality from traffic injuries ${ }^{35}$. In addition, the program seeks to promote safe and sustainable mobility in public spaces for the circulation of people. The program's priorities are the qualification of information to guide actions; the implementation of intersectoral and integrated actions on traffic law enforcement, education, infrastructure, health care and health promotion; interventions aimed at increasing the use of protective equipment, reducing speed, improving legislation and increasing enforcement actions focused on drink-drive behaviors and use of protective equipment; the improvement of sustainable urban transport and road infrastructure; prioritizing vulnerable groups of victims (motorcyclists, pedestrians, cyclists, and others identified locally); and strengthening intersectorality in the three management spheres ${ }^{36}$.

It is noteworthy that, although Brazil achieved a reduction in deaths from traffic accidents between 2010 and 2017, the mortality rates of motorcyclists continue to rise, constituting a permanent challenge to tackle traffic deaths and injuries in the country. Thus, it is recommended to strengthen and expand intervention programs that emphasize intersectorality, the use of qualified information and the planning and execution of actions based on local evidence, such as the PVT.

\section{REFERENCES}

1. Mascarenhas MDM, Souto RMCV, Malta DC, Silva MMA, Lima CM, Montenegro MMS. Características de motociclistas envolvidos em acidentes de transporte atendidos em serviços públicos de urgência e emergência. Ciênc Saúde Coletiva 2016; 21(12): 3661-71. http://dx.doi. org/10.1590/1413-812320152112.24332016

2. World Health Organization. Global status report on road safety 2015. Genebra: World Health Organization; 2015.

\footnotetext{
Morais Neto OL, Montenegro MMS, Monteiro RA, Rodrigues FR, Botacin CF, Beniz LAF. Perfil e evolução da morbimortalidade de acidentes de transporte terrestre-Brasil, 2004-2013. In: Saúde Brasil 2014: uma análise da situação de saúde e das causas externas, editor. Brasília: Ministério da Saúde, Secretaria de Vigilância em Saúde; 2015. p. 345-72. - Brasil. Ministério da Saúde. DATASUS. Mortalidade-Brasil [Internet]. [acessado em 25 out. 2016]. Disponível em: http:// tabnet.datasus.gov.br/cgi/tabcgi.exe?sim/cnv/obt10uf.def
} 
5. Talving P, Teixeira PG, Barmparas G, Dubose J, Preston C, Inaba K, et al. Motorcycle-related injuries: effect of age on type and severity of injuries and mortality.J Trauma 2010; 68(2): 441-6. https:// doi.org/10.1097/TA.0b013e3181cbf303

6. Diniz EPH, Assunção AÁ, Lima FPA. Prevenção de acidentes: o reconhecimento das estratégias operatórias dos motociclistas profissionais como base para a negociação de acordo coletivo. Ciênc Saúde Coletiva 2005; 10(4): 905 16. http:/ / dx.doi.org/10.1590/S1413-81232005000400014

7. Vasconcelos CH, Lima CM, Aquino EC, Montenegro MMS, Souto RMCV, Ramalho WM. Tendência e cenário da mortalidade por acidentes de transporte terrestre no Brasil, de 2000 a 2015. In: Saúde Brasil 2017: uma análise da situação de saúde e os desafios para o alcance dos objetivos de desenvolvimento sustentável, editor. [Internet]. Brasília: Ministério da Saúde, Secretaria de Vigilância em Saúde; 2018 [acessado em 08 set. 2019]. p. 293-312. Disponível em: http:/ / bvsms.saude.gov.br/bvs/ publicacoes/saude_brasil_2017_analise_situacao_saude_ desafios_objetivos_desenvolvimento_sustetantavel.pdf

8. Morais Neto OL, Montenegro MMS, Monteiro RA, Siqueira Júnior JB, Silva MMA, Lima CM, et al. Mortalidade por acidentes de transporte terrestre no Brasil na última década: tendência e aglomerados de risco. Ciênc Saúde Coletiva 2012; 17(9): 2223-36. http:/ / dx.doi.org/10.1590/S1413-81232012000900002

9. Biffe CRF, Harada A, Bacco AB, Coelho CS, Baccarelli JLF, Silva KL, et al. Perfil epidemiológico dos acidentes de trânsito em Marília, São Paulo, 2012. Epidemiol Serv Saúde 2017; 26(2): 389-98. http: / / dx.doi.org/10.5123 / S1679-49742017000200016

10. Paixão LMMM, Gontijo ED, Mingoti SA, Costa DAS, Friche AAL, Caiaffa WT. Óbitos no trânsito urbano: qualificação da informação e caracterização de grupos vulneráveis. Cad Saúde Pública 2015; 31(Supl. 1): 92-106. http: / / dx.doi.org/10.1590/0102-311X00081314

11. Organização Pan-Americana de Saúde. Trânsito: um olhar da saúde para o tema [Internet]. Brasília: OPAS; 2018 [acessado em 05 set. 2019]. Disponível em: http: / / iris.paho.org/xmlui/handle/123456789/49709

12. Bacchieri G, Barros AJD. Acidentes de trânsito no Brasil de 1998 a 2010: muitas mudanças e poucos resultados. Rev Saúde Pública 2011; 45(5): 949-63. http: / / dx.doi. org/10.1590/S0034-89102011005000069

13. Bastos YGL, Andrade SM, Soares DA. Características dos acidentes de trânsito e das vítimas atendidas em serviço pré-hospitalar em cidade do Sul do Brasil, 1997/2000. Cad Saúde Pública 2005; 21(3): 815-22. http:/ / dx.doi.org/10.1590/S0102-311X2005000300015

14. Souza HNF, Malta DC, Freitas MIF. Narrativas de motociclistas acidentados sobre riscos e os diversos meios de transporte. Interface 2018; 22(67): 1159-71. http: / / dx.doi.org/10.1590/1807-57622017.0333
15. Scarpetta J, Gonçalves OO. Incentivos fiscais e o aumento de custos da saúde pública: o caso da "epidemia" de motocicletas no Brasil. Veredas Direito 2015; 12(24): 227. http:// dx.doi.org/10.18623/rvd. v12i24.486

16. Organização Pan-Americana de Saúde. Salvar vidas. Pacote de medidas técnicas para segurança no trânsito [Internet]. Brasília: OAPS; 2018 [acessado em 08 set. 2019]. Disponível em: https: / / www.afro.who.int/pt/ publications/salvar-vidas-pacote-de-medidas-tecnicaspara-seguranca-no-transito

17. Organização Pan-Americana de Saúde. Capacetes: manual de segurança no trânsito para os gestores e profissionais de saúde [Internet]. Brasília: OPAS; 2007 [acessado em 08 set. 2019]. Disponível em: https:// www.paho.org $/$ bra/index.php?option $=$ com_docm an $\&$ view $=$ document $\&$ layout $=$ default $\&$ alias $=206$ capacetes-manual-seguranca-no-transito-para-osgestores-e-profissionais-saude-68category_slug=saudee-ambiente-707\&Itemid $=965$

18. Veronese AM, Oliveira DLLC. Os riscos dos acidentes de trânsito na perspectiva dos moto-boys: subsídios para a promoção da saúde. Cad Saúde Pública 2006; 22(12): 2717-21. http://dx.doi.org/10.1590/ S0102-311X2006001200021

19. Morais Neto OL, Andrade AL, Guimarães RA, Mandacarú PMP, Tobias GC. Regional disparities in road traffic injuries and their determinants in Brazil, 2013. Int J Equity Health [Internet]. 2016 [acessado em 17 out. 2019]; 15. Disponível em: http://dx.doi. org/10.1186/s12939-016-0433-6

20. Silva DW, Soares DA, Andrade SM. Atuação profissional de motoboys e fatores associados à ocorrência de acidentes de trânsito em Londrina-PR. Epidemiol Serv Saúde [Internet]. 2008 [acessado em 17 out. 2019]; 17(2). Disponível em: http://dx.doi.org/10.5123/ S1679-49742008000200010

21. Malta DC, Stopa SR, Silva MMA, Szwarcwald CL, Franco MS, Santos FV, et al. Acidentes de trabalho autorreferidos pela população adulta brasileira, segundo dados da Pesquisa Nacional de Saúde, 2013. Ciênc Saúde Coletiva 2017; 22(1): 169-78. http:/ / dx.doi. org/10.1590/1413-81232017221.17862015

22. Organização Pan-Americana de Saúde. Beber e dirigir: manual de segurança viária para profissionais de trânsito e de saúde [Internet]. Brasília: OPAS; 2007 [acessado em 15 ago. 2019]. Disponível em: https: / / www.paho.org/bra/index. php?option $=$ com_docman $\&$ view $=$ document $\&$ layo $\mathrm{ut}=$ default $\&$ alias $=1484$-beber-e-dirigir-prevencaomanual-seguranca-transito-para-profissionaistransito-e-saude-4\&category_slug=acidentes-eviolencias- 0868 Itemid $=965$ 
23. Brasil. Ministério da Saúde. Secretaria de Vigilância em Saúde. Vigilância de fatores de risco e proteção para doenças crônicas por inquérito telefônico - Vigitel 2018. Brasil: Ministério da Saúde; 2018 [acessado em 27 ago. 2019]. Disponível em: http:/ / svs.aids.gov.br/ download/Vigitel/

24. Macinko J, Mullachery P, Silver D, Jimenez G, Morais Neto OL. Patterns of Alcohol Consumption and Related Behaviors in Brazil: Evidence from the 2013 National Health Survey (PNS 2013). PLoS One 2015; 10(7): e0134153. http:/ /dx.doi.org/10.1371/journal.pone. 0134153

25. Damacena GN, Malta DC, Boccolini CS, Souza Júnior PRB, Almeida WS, Ribeiro LS, et al. Consumo abusivo de álcool e envolvimento em acidentes de trânsito na população brasileira, 2013. Ciênc Saúde Coletiva 2016; 21(12):3777-86. http:/ / dx.doi.org/10.1590/1413-812320152112.25692015

26. Golias ARC, Caetano R. Acidentes entre motocicletas: análise dos casos ocorridos no estado do Paraná entre julho de 2010 e junho de 2011. Ciênc Saúde Coletiva 2013; 18(5): 1235-46. http://dx.doi.org/10.1590/ S1413-81232013000500008

27. Keall MD, Newstead S. Analysis of factors that increase motorcycle rider risk compared to car driver risk. Accid Anal Prev 2012; 49: 23-9. http: / / dx.doi.org/10.1016/j. aap.2011.07.001

28. Instituto de Pesquisa Econômica Aplicada(IPEA). Acidentes de trânsito nas rodovias federais brasileiras: caracterização, tendências e custos para a sociedade - Relatório de pesquisa [Internet]. Brasília: IPEA [acessado em 27 ago. 2019]; 2015. Disponível em: http://www.ipea.gov.br/portal/index. php?option $=$ com_content $\&$ view $=$ article $\&$ id $=26277$

29. U.S. Department of Transportation, National Highway Transportation Safety Administration. Traffic Safety Facts 2010 Data: Motorcycles. Report No.: DOT HS 811639 [Internet]. Washington, D.C.: National Center for Statistics and Analysis [acessado em 20 mar. 2015]. Disponível em: http:/ / www-nrd.nhtsa. dot.gov/Pubs/811639.pdf
30. Brasil, Departamento Nacional de Trânsito. Código de Trânsito Brasileiro: instituído pela Lei $\mathrm{n}^{\circ}$ 9.503, de 23-9-97. $3^{\text {a }}$ ed. Brasília: DENATRAN; 2008.

31. Instituto Brasileiro de Geografia e Estatística,. Pesquisa nacional de saúde, 2013: acesso e utilização dos serviços de saúde, acidentes e violências: Brasil, grandes regiões e unidades da Federação. Rio de Janeiro: Instituto Brasileiro de Geografia e Estatística; 2015.98 p.

32. Brasil. Ministério da Saúde. Viva: Vigilância de Violências e Acidentes, 2008 e 2009 [Internet]. Brasília: Ministério da Saúde. Secretaria de Vigilância em Saúde; 2010 [acessado em 28 ago. 2019]. Disponível em: http: / bvsms.saude.gov.br/bvs/publicacoes / viva_2008_2009_violencias_acidentes.pdf

33. Elvik R, editor. The handbook of road safety measures. $2^{\text {a }}$ ed. Bingley: Emerald; 2009. 1124 p.

34. Peden MM, World Health Organization, editors. World report on road traffic injury prevention. Genebra: World Health Organization; 2004. 217 p.

35. Morais Neto OL de, Silva MMA, Lima CM de, Malta DC, Silva Jr. JB da. Projeto Vida no Trânsito: avaliação das ações em cinco capitais brasileiras, 2011-2012. Epidemiol Serv Saúde 2013; 22(3): 373-82. http:// dx.doi.org/10.5123/S1679-49742013000300002

36. Brasil. Ministério da Saúde. Guia Vida no Trânsito. Brasília: Ministério da Saúde, 2017.

Received on: 10/25/2019

Revised on: 12/24/2019

Accepted on: 01/07/2020

Author's contributions: RMCV Souto participated in the conception and design of the study, in the writing of the article, and in the approval of the final version to be published. RB Corassa participated in the design and analysis of the data, in the writing of the article, and in the review and approval of the final version. DC Malta and CM. 